\title{
THE MANIFESTATIONS OF GIFTED CHILDREN FROM THE PERSPECTIVE OF THEIR PARENTS
}

\author{
Eva Machů
}

\begin{abstract}
The article deals with the problematics of gifted children. It describes the findings of a qualitative research with the aim of describing particular typical manifestations of children' giftedness from the perspective of their parents. The source of data was a group interview with eight parents of gifted children who regularly meet within the Gifted Children Parents Club. The interviews were transcribed and the data gained subsequently elaborated using the cluster analysis. On the basis of similarities between identified units seven semantic categories were created. These categories include particular examples and real stories which illustrate specific manifestations of children' giftedness. The research findings present a practical completion of available lists of gifted children typical characteristics.
\end{abstract}

\section{Key words}

Gifted child, characteristics of gifted children, manifestations of gifted children, parenthood of a gifted child, qualitative research.

\section{INTRODUCTION}

The topic of gifted children still maintains one of the most prominent positions among today's most actual topics. School conditions for education of gifted children improve, the teachers' qualifications rise, the number of professionals and laypeople, who are aware of the necessity to help these children develop, also rises. It is a multidisciplinary issue, concerning not only professionals such as psychologists, pedagogues and pediatricians, but also laypeople. This topic offers a great amount of unlimited possibilities of research seizing.

Our article focuses on the characteristics and manifestations of gifted children. The topic is very popular and very often described, because it is one of the starting points for the proper diagnostics of giftedness. Lists of gifted children 's typical characteristics, which serve as indication for identification of gifted children by parents and teachers, can be more easily found in world literature (e. g. David, Rimm, 1998; Freeman, 1998; Porter, 1999). In Czech literature, we can found characteristics of gifted children and lists of typical manifestations in the works of Hř́bková (2005), Fořtík, Fořtíková (2007), Machů (2010) etc. 
If we were to present one of the samples of these lists, we would choose e. g. Porter (1999), who names these typical manifestations of gifted children, which the author divides into cognitive area and affective area. Furthermore, this taxonomy may be a suitable starting point for our realized research.

Gifted children's manifestations in the cognitive area:

- They have excellent logical memory; Their learning is quicker and of a better quality; They use advanced thought processes; They can understand abstract concepts better than their peers; They see unusual relations and links; They show good observation skills; They are able to differ even insignificant details; They manifest developed vocabulary; They have many different hobbies; They are able to concentrate in the field of their interests in long terms; They are able to read with comprehension in the preschool age; They have a great knowledge in specific areas of interest.

Gifted children's manifestations in the affective area:

- They are internally motivated, persistent, competitive; They subordinate to authorities unwillingly; They possess a sense of humor; They have a developed sense of moral and justice; They do not like subordinating to rules; They are overly sensitive; They have extraordinary sensory perception; They have high requirements for themselves and other people; They are aware of their own distinction.

Our research deals with manifestations and characteristics of gifted children from the viewpoint of the parents of gifted children. The aim is to find out, which manifestations of giftedness do the parents of gifted children register, and illustrate these manifestations with specific examples and stories. This research employs the methods of qualitative research, as they may help us discover specific examples in a real context.

\section{RESEARCH METHODOLOGY}

Research design: qualitative

Type of the research problem: descriptive

Main aim of the research: The aim of the research was to discover and describe specific examples of typical manifestations of giftedness of the children from the viewpoint of their parents.

Research sample - parents of gifted children: Seven mothers of gifted children participated in the research. The research sample was chosen deliberately. We contacted individuals, i. e. mothers, who attend the regular meetings of the Gifted Children Parents Club. The mothers were aged from 29 to 41 . The gifted children 
were diagnosed with intellectual giftedness in the Psychological and Counseling Center. In this article, a gifted child equals a child with intellectual giftedness. The following figure shows that the age of the gifted children ranges from 6,5 to 14 years. The group of gifted children is significantly heterogeneous in the matter of age. This heterogeneity is not an obstruction for the research, as the parents of the gifted children were questioned not only about contemporary, but also early manifestations of giftedness. Furthermore, the age of the child in question is recognizable from the parent's individual commentary.

\begin{tabular}{||l|l|l||}
\hline Parent: & $\begin{array}{l}\text { Gifted child's age, } \\
\text { amount of children }\end{array}$ & $\begin{array}{l}\text { School, the gifted child is attending } \\
\text { to }\end{array}$ \\
\hline Woman, 35 & Boy, 10 & Eight-year Grammar school \\
\hline Woman, 37 & Girl, 6,5 & Common Kindergarten/integration \\
\hline Woman, age N/A & $\begin{array}{l}\text { Girl, 12+1 sibling not } \\
\text { diagnosed } \\
\text { with giftedness }\end{array}$ & $\begin{array}{l}\text { Common Primary school/ } \\
\text { integration }\end{array}$ \\
\hline Woman, 29 & Girl, 7 & Specialized class for gifted pupils \\
\hline Woman, 31 & Boy, 10 & Eight-year Grammar school \\
\hline Woman, 41 & Boy, 14 & Eight-year Grammar school \\
\hline Woman, 41 & Boy, 6,5 & $\begin{array}{l}\text { Specialized Kindergarten } \\
\text { for gifted children }\end{array}$ \\
\hline
\end{tabular}

Fig. 1 - Basic information about informants

Data sources and data processing: The research was executed as a part of a regular meeting of parents of gifted children, in so called Gifted Children Parents Club. Data was gathered using the group discussion (Miovský, 2006). Semistructured interview with eight informants was executed during the group discussion. The discussion lasted approximately for an hour. In the beginning, the informants wrote basic information about themselves on cards (see fig. 1) and then they were asked the starting questions, which enabled asking any additional supporting questions. The main, starting questions included:

- How did the giftedness of your children use to manifest and how does it manifest now?

- In your opinion, what are the specifics of gifted children in comparison with their peers?

- What specifics does the parenthood of a gifted child possess? 
Group interaction was intentionally not encouraged (in contrast with the methods of focus groups) during the group discussion. The informants' answers during the group discussion led to new issues thematically related with the starting questions.

The acquired interviews were rewritten and consequently processed using the method of clustering (Miovský, 2006). Data were classified into groups (semantic categories) based on the thematical similarities between identified units with consideration about the main aim of the research. Specific identified thematic units leading to the creations of semantic categories are also stated in the research.

\section{DESGRIPTION OF NEWLY CREATED SEMANTIC CATEGORIES}

The following seven categories were identified from the interviews:

\section{1. category: Early reading, writing and counting}

The identified thematic units leading to the creation of a semantic category: early reading, reading as a hobby, trivial education is not purposeful, family is surprised by the reading ability, early writing, early counting, to teach or not to teach?, giftedness - distinction from peers, establishing relationships.

According to the informants' statements, the manifestations of children's giftedness are connected mainly with the fact that they have reading as a hobby, be it in the passive form of listening, or own active reading. "He likes it when you read to him, but everything he needs, he looks up on his computer." Another mother of a preschool child confirms: "He reads what he needs to, but books, fairytales, that's up to us." Parents also add that they did not purposefully develop their preschool children's ability to read and consecutively also the ability to write: "When our daughter was four years old, she started writing. Nobody led her to it. She was really galvanized by this activity." Another informant talks about the manifestations of this skill: "As a two-year old, she really astonished everybody at the bus stop, when she started calling out the numbers written on the passing trolleybuses,... or later, when she was about four, she would read aloud the signs on posters. And mind you, she wasn't purposefully led to this skill."

The early reading and writing abilities are also connected with emergences of parents' various dilemmas. Let the children write phonetically or teach them grammar? "We were wondering, if we should let her write phonetically, or start to explain the basic grammar rules, so that she wouldn't have problems in school, where she would have to learn it anew... and then the problem solved itself...she started learning the grammar naturally by herself." Another problem is connected with the beginning of school attendance: "They told us she would 
have problems when she goes to school, that she would get bored and she would disturb everybody. But then a psychologist told us we can't hold our daughter back, that the school would have to adapt to our daughter's individuality.'

The trivial mastery in the early age is also connected with the problems with peer relationships, when gifted children experience difficulties in finding an adequate communication partner: "He is in a club and they had to draw something, those snails for hand relaxation. He had finished, so he counted his snail and he said: 'I made 35 snails, what about you?' And his friend said: 'I don't know.' 'So count them, ' he replied. 'I can 't do that.' Vašek was shocked that his friend wasn't able to count his snails, and his friend was shocked that Vašek was able to do that." Another mother contributes another story, but she adds, that it is an experience of her friend, who is also a mother of a gifted child. In this case, the main theme is the early speaking ability. "He would go around the sandbox and asked every child: 'Can you speak? Can you speak? And you, can you speak?" "Another informant claims that the distinction resulting from the early trivial mastery may be the cause of mutual disputes between children. "She was put into a group of preschool children, who were a year older. There she experienced bullying, because they found out she was able to read and write and count."

\section{2. category: Sense of humor}

Identified thematic units leading to the creation of the semantic category: specific sense of humor, mature sense of humor, punch lines not understood by others.

According to the parents interviewed, another typical characteristic of gifted children is a specific sense of humor. "It was clear very soon that he has a sense of humor. Like a 'cimrmanologist.' He has that sort of a totally abstract humor." Another mother describes her child's sense of humor with an unusual example: "Our guinea pig died and we were putting off digging of a grave... And Jirka said: "Maybe on Friday." And I said: "Jirka, children are coming for your birthday party on Friday." And he said: "Well, since they will be here..." And she adds: "His humor, that's a joke, an absurd pun, a play on words. Adults don't understand it and nor do children."

The specificity of the sense of humor describes another mother: "It's like she plays around in her mind until she comes up with a pun or a play on words and then she's amused really good." Another informant illustrates this case: "When she was three and a half and she wasn't behaving, we told her the naughty children would be taken away by the devil. Then she was being naughty between the Saint Nicholas Day and the Christmas Eve so her mother says: 'Aren't you afraid that you won't get any presents, since you're so naughty?' And she said: 'I'm not afraid, the naughty children were all taken away by the devil." 


\section{3. category: Competitiveness}

Identified thematic units leading to the creation of semantic category: competitiveness, cannot stand losing, competitiveness - problems in the group of children.

Competitiveness is another gifted children's characteristic which was mentioned by the informants. It was stated: "He is really competitive ... he likes competing in everything... be it running up the stairs or a game of Ludo." Another informant adds: "...but he really hates losing and he takes it really bad and becomes so upset that he starts acting up. It's an adrenaline rush."

According to the parents, competitiveness also influences the selection of activities the child wants to pursue. "She's really competitive. She likes playing tennis, dodgeball, the types of sport where you can win something. She probably wouldn't do aerobics, she wouldn't be motivated to do it."

Other parents mention the competitiveness and its manifestations in the intentional areas: "She's still competing even with her friends in the Kindergarten, she has to be the best in absolutely everything." The parents also realize the competitiveness leads to the gifted child's exclusion from the group of children. 'Our daughter always competes to be the 'Maths king.' She was always the Maths king and she's also won every other trivia challenge, which of course contributed to the exclusion from the group. Sometimes she rather let another child win the competition."

\section{4. category: Insufficient learning habits and deep learning style}

Identified thematic units leading to the creation of the semantic category: parents' support of learning, insufficient learning skills, deep learning style.

When answering the question, what the parenthood of a gifted child is like, the interviewees mentioned the need of an extraordinary education, even in the family surroundings: "...my friends think that when we have a gifted child, we don't have to help them with learning. That's not true. It seems to me, that we have to help them even more." Another interviewee adds information about learning skills: "Although our child is gifted, we have to help her with learning. She isn't able to sit still and learn, so she isn't able to manage and plan the learning." Another informant describes directly the insufficient learning skills of her child and adds a cause which, according to her, may be leading to this problem: “...she has never learned how to learn, because she didn't need to. Her memory was really good, she was always asking about everything... But the things she has to learn now, such as physics and chemistry, I have to do it with her, or control her, how she studies." 
Concerning the learning style, parents claim that the gifted children prefer deep learning style. 'Learning by heart isn't a problem for her, but she doesn't like it. She's not interested in facts, she cares about the principles. So she's not interested in history, because that's just facts, which, according to her, may be distorted. But principles, like Physics, Maths, how things work, that's really interesting for her."

\section{5. category: Hobbies and favorite activities}

Identified thematic units leading to the creation of the semantic category: numerous hobbies, intellectual characteristic hobbies, development of hobbies.

According to the interviewed parents, giftedness manifests itself in the fact that the gifted children have numerous hobbies. Parents were asked about the characteristics of their children's favorite hobbies. "He prefers natural sciences, such as physics, chemistry. He wants to do medicine research or biochemistry." The interviewee presents further activities: "He's in a meteorology club, he's interested in computers..." Another informant lists other examples: "She wasn't interested in dolls. She's always liked blocks the best, she had to think about them. Later, it was Scrabble and Sudoku. When she watched TV, she liked especially documentaries about nature, travelogues, her favorite cartoons were shows such as Once Upon a Time... Life, Once Upon a Time... The Discoverers."

Parents also mentioned that their children's favorite activities develop according to the situation and current stimuli: "His hobbies develop. He has some sort of periods, when he for example writes a book, plays with the construction toy Merkur, builds a toy car track on his own, cuts out and makes various paper miniatures of real machines, reads books, thinks up various quizzes... and then he does something else, something he becomes excited about." "If she becomes interested in something, she spends the whole afternoon doing it, every day after returning from school. For example she does all the home assignments. When she comes across the name Vincent Van Gogh and gets interested in him, she explores everything about him... and then she makes an Open Office presentation about him for us.'

The tendencies to intellectual activities are also evident in the artistic activities the children spend their time with: "He plays the flute and piano, he tries to compose his own compositions." Another informant adds: "She's liked drawing since she was a little child. Her artistic abilities weren't so amazing, regarding the aesthetics. But the attention to details was evident from the drawings. She liked to draw national flags from the world atlas and then she examined the whole family, whether we knew, which flag belongs to which nation." 


\section{6. category: Regular routine and perfectionism}

Identified thematic units leading to the creation of the semantic category: liking for a regular routine, logic of creating rules, perfectionism.

Another gifted children's characteristic mentioned by the parents interviewed is the liking for a regular routine and established rules: "My husband gets our son off to school. They have such a morning routine that everything connects... and they leave the house at 8:10. And once I was standing in for my husband, and I didn't know about the morning routine, it was about 8:07 and said: 'Hey, we should go now.' And Jirka said: 'We're leaving at 8:10, mom!'” Another informant contributes her story: "He came back from a school trip which lasted for a few days. He falls asleep late at night, so I gave him a game of mine. When he can't fall asleep he plays this game. And he said: 'Mom, I had to break the rules. When we were supposed to sleep, we could have got out of bed only when we had to go to the bathroom. And I got out of bed to get my game.'" Another interviewed parent stated that the established rules must be seen as logical by the children. "They follow the rules religiously. When there are some established rules, he can't stand somebody breaking them ... but not every single rule... I always have to explain to him why it is good to follow the rule."

Rules are connected with perfectionism and attention to detail, which the parents also mentioned in the interviews: "My daughter was drawing a picture. I asked her: 'You haven't finished, have you?' 'Yes, 'she replied. When I went to see the picture, she still hasn't finished the picture. She was actually right. 'Yes: it's not finished." Perfectionism is illustrated with other examples: "I asked him... 'Please, can you bring me the blanket which is in the bedroom, on the chair next to the window?' He replied: 'It was on two chairs, mom!' So he didn't bring it." One of the informants refers to her friend, also a mother of a gifted child: "She came to school to the locker room to pick up her first grader and she told him: 'Take your shoes and come.' And she went to wait for him in front of the school. And he came barefoot holding the shoes in his hands."

\section{7. category: Refusal to accept authoritarian leadership}

Identified thematic units leading to the creation of the semantic category: refusal of forced authority, need for a logical explanation of everything.

The interviewed parents agreed that authoritarian leadership is not suitable for their children: "Their favorite teacher went on a maternity leave in the middle of the school year. Then they got a teacher who was really old-fashioned. Downright authoritarian. My daughter refused to go to school. Even her grades got worse at that time." Another parent adds: "Since she was a little 
child, she's been able to recognize who has a natural authority and who does$n$ 't. She obeys and listens to the person that has a natural authority and she refuses to obey the person who forces their authority." Consecutively, she adds: "All the adults, whom she met in school, kindergarten, summer camps, they admired her or hated her because of this." Another informant informs about a different consequence of the authoritarian leadership: "He doesn't let anyone order him anything. He doesn 't like orders... He's willing to take every abstract or invalid order to extremes. When told to greet he greeted everybody we met in the city and jokingly looked at me to see what the consequence would be."

Consecutively, another informant adds: "But it doesn't mean that I'm not going to be an authority and he is going to do anything he wants to...it's about explaining my order... I had to explain what was wrong about it and why it was wrong. Then he understood. There has to be a logical explanation. Then the problem goes away and suddenly he has a tendency to sort of apologize and explain himself and he is, like, alright."

\section{SUMMARY AND CONGLUSION}

The aim of the qualitatively oriented research was to discover and describe specific typical examples of manifestation of children's giftedness from the viewpoint of their parents. Data, which were acquired with the help of interviews with gifted children's parents, were subsequently processed using the method of clustering. Seven semantic categories, based on the similarities between the identified units, were created.

The following are the summaries of the individual semantic categories:

- Early reading, writing and counting: The ability of early reading, writing and counting is a typical manifestation of the children's giftedness, which was confirmed by the interviewed parents' statements. It was discovered that the parents do not intentionally develop these ability. This ability is also connected with emergences of the parents' various dilemmas, such as: Hold the child back, so it would not be bored in school? Let the child write phonetically or teach the child grammar? The interviewees also realize that the early trivial knowledge may be the cause of mutual disputes between the gifted child and their peers.

- Sense of humor: This is another typical characteristic often appearing in lists of manifestations of children's giftedness. The parents illustrate this with various examples. The gifted children's humor is described as specific, very mature and thus hardly understandable by their peers.

- Competitiveness: Another typical characteristic appearing in lists of gifted children's manifestations is competitiveness. According to the parents, this 
is what greatly motivates the children. Once more, they add that it may be a cause of the child's exclusion from their peer group.

- Insufficient learning habits and deep learning style: The interviewees described their children's insufficient learning habits. As James T. Webb (2002) stated: the insufficient learning habits are on of the possible and typical causes of gifted children's problems. The parents who mentioned this manifestation admitted that they regularly help their children with learning. Concerning the learning styles, the gifted children prefer deep learning styles, according to the parents.

- Hobbies and favorite activities: According to the parents, gifted children have numerous hobbies which they gladly and actively pursue. The hobbies are of intellectual characteristics. This was also noted by the parents in their children's artistic activities.

- Regular routine and perfectionism: This category, in which the parents describe the liking of a regular routine and rule-following, may seem surprising, as it does not usually appear in the lists of gifted children's typical characteristics and manifestations. It is very important to add that a logical reason of the rules must be explained to the children. Rule-following is connected with perfectionism and attention to detail, which were also mentioned in the interviews with the parents.

- Refusal to accept authoritarian leadership: According to the parents interviewed, the gifted children refuse to let themselves be subordinated to authoritarian leaders. They add that they do not use libertarian leadership. They claim that every order has to be logically reasoned.

The created semantic categories are a list of gifted children's typical manifestations from the viewpoint of the parents who participated in this research. The results of the research are not to be generalized to the whole population of identified intellectually gifted children.

As the figure below illustrates, the discovered manifestations of gifted children can be separated into cognitive and affective areas. As these areas mutually overlap, the figure indicates whether the specific manifestation relates more to the cognitive or affective area. 


\section{Gifted children's manifestation:}

D Early reading, writing and counting. Manifestations in the cognitive area

\Sense of humor

Insufficient learning habits and deep learning style.

Competitiveness.

D Regular routine and perfectionism.

$\rightarrow$ Refusal to accept authoritarian leadership

Manifestations in the affective area

Fig. 2 - gifted children's manifestations from their parent's point of view

The componential research output may serve as particular practical illustration of existing lists of gifted children's typical manifestations.

\section{List of literature and professional sources}

Davis, G., Rimm, S., \& Siegle, D. (1998). Education of the Gifted and Talented. Needham Hights: Allyn \& Bacon.

Fořtík, V., \& Fořtíková, J. (2007). Nadané ditě a rozvoj jeho schopností. Praha: Portál.

Freemanová, J. (1998). Educating the Very Able. Current International research. London: Stationery Office.

Hř́bková, L. (2005). Nadání a nadani: pedagogicko-psychologické přistupy, modely, výzkumy a jejich vztah ke školské praxi. Praha: UK.

Machů, E. (2010). Nadaný źák. Brno: Paido.

Miovský, M. (2006). Kvalitativni př́stup a metody v psychologickém výzkumu. Praha: Grada.

Porter, L. (1999). Gifted Young Children. A Guide for Teachers and Parents. Buckingham: Open University Press.

Švaříček, R., \& Šed'ová, K. (2007). Kvalitativni výzkum v pedagogických vědách. Praha: Portál.

Webb, J. T. (2002). Guiding The Gifted Child: A Practical Source for Parents and Teachers. Scottsdale : Gifted Psychology Press. 


\section{Acknowledgements}

Acknowledgement is made to Bc. Michaela Blahová, student of the Pedagogical Department of the Faculty of Humanities at TBU, for helping with the qualitative data collection. This contribution was made thanks to the support of the Tomas Bata University in Zlin and the project IGA, no. IGA/66/FHS/11A.

\section{Contact:}

Mgr. Eva Machů, Ph.D.

Department of Pedagogical Sciences

Faculty of Humanities, Tomas Bata University in Zlín

nám. T. G. Masaryka 1279

76001 Zlín

Czech Republic

Phone: +420 576037418

E-mail: machu@fhs.utb.cz 